\title{
Determination of moisture diffusivity and activation energy in the convective drying of fish
}

\section{Clement Adekunle Komolafe ${ }^{1 *}$, Iyiola Olusola Oluwaleye ${ }^{2}$, Akinfoye O. Daniel Adejumo ${ }^{3}$, Mufutau Adekojo Waheed ${ }^{4}$, Sidikat Ibiyemi Kuye ${ }^{4}$}

\author{
${ }^{1}$ Department of Mechanical Engineering, Landmark University, P.M.B. 1001, Omu Aran 251101, Nigeria \\ ${ }^{2}$ Department of Mechanical Engineering, Ekiti State University, P.M.B. 5363, Ado Ekiti 360001, Nigeria \\ ${ }^{3}$ Department of Agricultural Engineering, Federal College of Agriculture, P.M.B. 5092, Ibadan 200272, Nigeria \\ ${ }^{4}$ Department of Mechanical Engineering, Federal University of Agriculture, P.M.B. 2240, Abeokuta 110253, Nigeria
}

Corresponding author E-mail: komolafe.adekunle@lmu.edu.ng

https://doi.org/10.18280/ijht.360414

Received: 25 May 2018

Accepted: 13 August 2018

\section{Keywords:}

Tilapia fish, convective drying, moisture diffusivity, activation energy

\begin{abstract}
The moisture diffusivity and activation energy of three tilapia fish varieties were determined under convective drying process (CDP). A locally fabricated drying system was used for the experiment at $60,90 / 60$ and $90{ }^{\circ} \mathrm{C}$ drying air temperatures. The drying rate showed falling rate period for all the drying processes with no sign of constant rate period. The moisture diffusivity values which increased with the increase in drying air temperature varied from $7.821 \times 10^{-11}$ to $4.591 \times 10^{-10} \mathrm{~m}^{2} / \mathrm{s}$. The predicted Arrhenius constant and activation energy were $2.221 \times 10^{-10}$ $\mathrm{m}^{2} / \mathrm{s}$ and $23.79 \mathrm{~kJ} / \mathrm{mol}$ respectively.
\end{abstract}

\section{INTRODUCTION}

Fish, due to its high protein content and nutritional value is being considered a crucial food component in people's meal all over the world [1]. Reduction of moisture content from 80 to $25 \%$ will reduce autolytic activity and also prevent bacteria from surviving. However, further reduction of moisture content to $15 \%$ or less will stop mould growth during storage [2].

Traditionally, drying of fish is usually done in the open sun on the rack or on a raised smoking platform or three stone stove where control of heat is difficult and at times impossible [3]. The traditional technique is characterized with shortcomings such as weather dependency, insect infestation, etc. and the result is usually unsatisfactory end products. However, if acceptable and suitable drying temperature(s) are adopted under a controlled environment, post-harvest losses incurred as a result of under-drying and over-drying would be greatly reduced.

Heat and mass transfer, moisture diffusion and activation energy are the basic physical and thermal properties of agriculture materials necessary for ideal dryer design [4]. Moisture diffusivity is strongly dependent on temperature and the moisture content [5]. The level of dependency of temperature on the diffusivity is usually described by the Arrhenius equation, and that of moisture content on diffusivity can be introduced in the Arrhenius equation by considering either the activation energy or the Arrhenius factor as an empirical function of moisture [5]. Designing and modelling of mass transfer processes such as dehydration, adsorption and desorption of moisture during storage needs knowledge of moisture diffusivity [6].

Drying methods (simplified, regular regime and numerical solution methods) are one of the various techniques for determining experimentally moisture diffusivity in solids [5]. Moisture diffusivity is a transport property related to solid's drying or dehydration phenomena. Diffusion in solids during drying may involve the following: molecular diffusion, capillary flow, Knudsen flow, hydrodynamic flow, or surface diffusion. Moisture diffusivity if accurately predicted can lead to optimization of the drying process [7]

Several studies have been reported on modelling of drying kinetics, heat and mass transfer, moisture diffusivity and activation energy of fish $[8,9,10,11]$, other agricultural products under different drying conditions such as ginger [12], tomato [13], tomato leathers [14], grape leaves [15], olive pomace [16], rough rice [17], rumbutan seed [18], star fruit slices [19], cocoyam slice [20], pomegranate arils [6] and surface building materials [21]. However, no work seems to have been reported on the moisture diffusivity and activation energy of three tilapia fish varieties (mackerel, pilchard and herring) under a locally developed convective drying system. This study was therefore undertaken to determine the drying kinetics, moisture diffusivity and activation energy of three common tilapia fish varieties in Nigeria markets namely: mackerel (Scomber scomber spp.), pilchard (Sardina pilchardus spp.) and herring (Clupea harengus spp.) during convective drying process.

\section{MATERIALS AND METHODS}

\subsection{Experimental set-up}

A locally fabricated convective drying system (shown pictorially and schematically as in Figurers 1 and 2) capable of operating at desired drying temperature and blower speed was used for the study. Major components of the drying system are well insulated drying chamber, drying cage with tray (made from stainless steel wire mesh of $2.8 \mathrm{~mm}$ diameter), a blower (to push the heated air into the drying 
chamber) and a thermostat with sensor.

\subsection{Sample preparation}

Three common varieties of fresh tilapia fish in Nigeria market namely: Mackerel, Pilchard and Herring obtained from local fish market at Ibadan, Nigeria were used for the study. The frozen fish samples brought to the laboratory were washed thoroughly, head were cut-off. Later, the body without head was pre-treated by soaking in brine solution following the method described by [22]. Thereafter, the pretreated samples were thoroughly rinsed with clean water to prevent the salt crystal from depositing on fish surface as drying process progresses. The pretreated fishes were then arranged in single layer inside the pre-weighted mesh tray outside the drying chamber and left to drain for five minutes [23].

\subsection{Drying procedure}

The drying experiments were conducted at Ibadan, Nigeria, latitude $7^{\circ} 22.5^{1} \mathrm{~N}$ and Long $3^{\circ} 50.5^{1} \mathrm{E}$ at constant drying chamber temperature of $60,90 / 60$ (i.e. drying at high temperature at initial stage and later at lower temperature) [24] and $90^{\circ} \mathrm{C}$. Selection of these temperatures was based on the submission of Raham [24] that the drying temperature of fish must be at or above $60^{\circ} \mathrm{C}$ to avoid microbial risk in the product. Each fish variety already pretreated and weighed was dried at constant drying time of $8 \mathrm{hrs}$ ( 8 a.m to 4 p.m) [25] on separate day at $60,90 / 60$ and $90^{\circ} \mathrm{C}$. In order to control drying air temperature, a thermostat with sensor (probe) was fixed to the wall of the drying chamber. At intervals of 30 minutes in each experiment, the tray was taken out and weighed quickly to measure moisture loss.

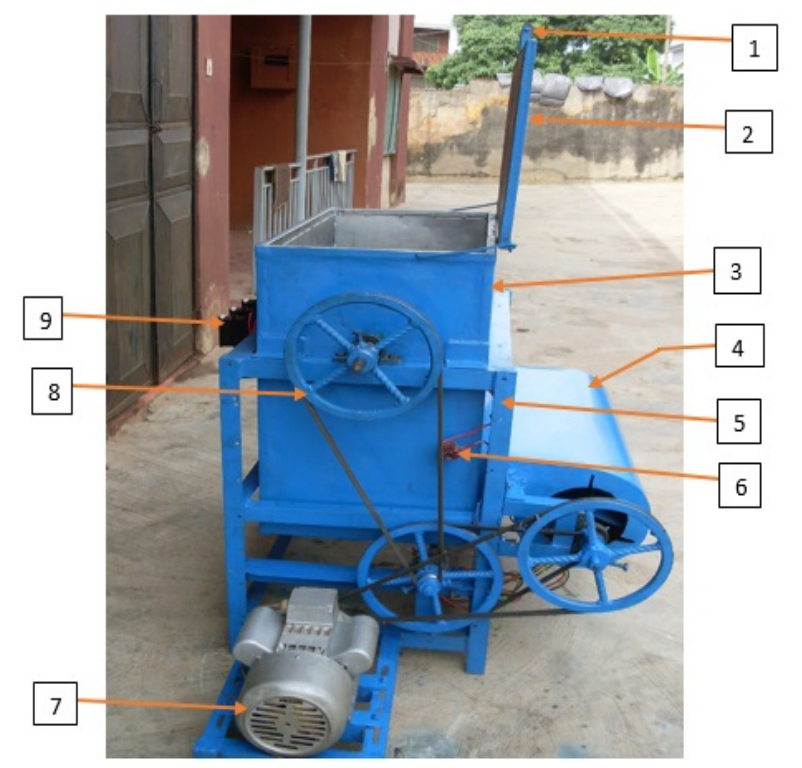

1. Wooden handle 2. Drying chamber cover 3. Drying chamber 4. Blower housing 5. Supporting frame 6. Thermostat 7. Electric motor 8. Drying cage pulley 9. Electric switch

Figure 1. Pictorial diagram of the convective drying system

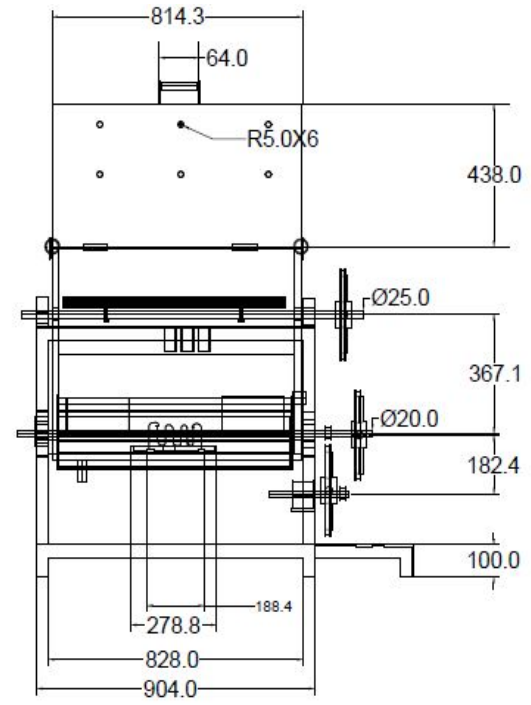

Figure 2. Schematic front view of the convective drying system

\subsection{Drying kinetics}

The moisture content on wet basis $\left(\mathrm{M}_{\mathrm{t}}\right)$ was calculated according to [26] as:

$\mathrm{M}_{\mathrm{t}}=\frac{W_{i-} W_{b d}}{W_{i}}$

where $\mathrm{M}_{\mathrm{t}}$ is the moisture content (\% w.b.); $\mathrm{W}_{\mathrm{i}}$ the initial weight of the sample $(\mathrm{g})$ and $\mathrm{W}_{\mathrm{bd}}$ the final weight of sample (g).

The dimensionless variable of moisture ratio (MR) of fish was calculated according to [27] using:

$M R=\frac{M_{t}-M_{e}}{M_{o}-M_{e}}$

where $M_{t}, M_{o}$ and $M_{e}$ are the moisture content measured at time t, initial moisture content, and equilibrium moisture content respectively. The value of $\mathrm{M}_{e}$ is very small compared to $\mathrm{M}_{t}$ or $\mathrm{M}_{\mathrm{o}}$ for long drying time. Thus eqn. (2) can be simplified according to [28] as

$M R=\frac{M_{t}}{M_{o}}$

The drying rate (DR) of fish was expressed using eqn. (4) $[29,30]$ as:

$D R=\frac{M_{t}-M_{t+d t}}{d t}$

where $M_{t+d t}$ is moisture content (g water/g wet solid) at $\mathrm{t}+$ $d t$, $\mathrm{t}$ is the drying time (hr) and $d t$ is change in time (hr).

The drying rate is defined as moisture diffusion from the inside to the outside layer. This can be explained by Fick's second law of diffusion for unsteady state diffusion.

\subsection{Moisture diffusivity}

The moisture diffusivity is a general property of moist involving the following: liquid diffusion, vapour diffusion, hydrodynamic flow and other possible mass transfer mechanism [31]. Assume fish in the form of approximated slab, the Fick's second law of diffusion adopted to fit the 
experimental data for determining moisture diffusivity is expressed according to [15] as:

$\frac{\partial M}{\partial t}=D_{e f f} \nabla^{2}$

The analytical solution of eqn. (5) for slab geometry using the following assumptions: uniform initial moisture distribution, negligible external resistance, constant diffusivity and negligible shrinkage [32] is given as:

$M R=\frac{8}{\pi^{2}} \sum_{n=1}^{\infty} \frac{1}{2 n-1} \exp \left(\frac{(2 n-1)^{2} \pi^{2} D_{e f f} t}{4 L^{2}}\right)$

where $\mathrm{L}$ is sample's half-thickness $(\mathrm{m}), \mathrm{t}$ is the drying time (s), $\mathrm{n}$ is a positive integer and $\mathrm{D}_{\text {eff }}$ is the moisture diffusivity. Linearizing eqn. (6) $[29,33]$ as follows:

$\ln (M R)=\ln \left(\frac{8}{\pi^{2}}\right)-\left(\frac{\pi^{2} t D_{e f f}}{4 L^{2}}\right)$

The slope of the curve from the plots of $\ln$ MR data against time data is constant of the above linear equation (eqn.7) and the moisture diffusivity was calculated using:

$D_{\text {eff }}=$ slope $\times \frac{4 L^{2}}{\pi^{2}}$

The moisture diffusivity can also be calculated using the Arrhenius equation:

$D_{\text {eff }}=D \exp \left(-\frac{E}{R T}\right)$

where $\mathrm{D}$ is the pre-exponential factor of the Arrhenius equation (Arrhenius constant) $\left(\mathrm{m}^{2} / \mathrm{s}\right), \mathrm{E}$ is activation energy $(\mathrm{kJ} / \mathrm{mol}), \mathrm{R}$ is universal gas constant $(8.314 \mathrm{~J} / \mathrm{mol} . \mathrm{K}), \mathrm{T}$ is absolute temperature (K).

\subsection{Activation energy}

The Microsoft Excel SOLVER tool was used for the prediction of the Arrhenius constant and activation energy.

\section{RESULTS AND DISCUSSION}

\subsection{Drying kinetics}

Figures. 3-5 show variation in moisture content with the time during the convective drying experiments of three tilapia fish species at $60,90 / 60$ and $90{ }^{\circ} \mathrm{C}$ drying temperature. From the Figurers, the moisture content continuously decreases as drying process progresses. At 60 ${ }^{\circ} \mathrm{C}$, the initial moisture content of mackerel, pilchard and herring within 8 hrs of drying, reduced from 66.3, 67.3 and $66.2 \%$ w.b. to $13.0,16.5$ and $14.7 \%$ w.b respectively. Similarly, at $90 / 60{ }^{\circ} \mathrm{C}$ and $90{ }^{\circ} \mathrm{C}$, the initial moisture content of the three tilapia fish species reduced within the same period ( $8 \mathrm{hrs}$ ) from 73.0, 70.6 and $65.2 \%$ w.b.; and 68.3, 71.1 and 66.1 w.b. to $16.3,17.9$ and $13.5 \%$; and $12.4,14.6$ and $12.3 \%$ respectively. The drying curves indicate absence of constant rate drying period. The drying process dominantly occurred under falling rate period. The continuous decrease in moisture content is an indication that diffusion is the physical mechanism governing the internal mass transfer. This is in congruent with the results of study on silverside fish [4], prawn and chelwa fish [22] and pomegranate arils [6].

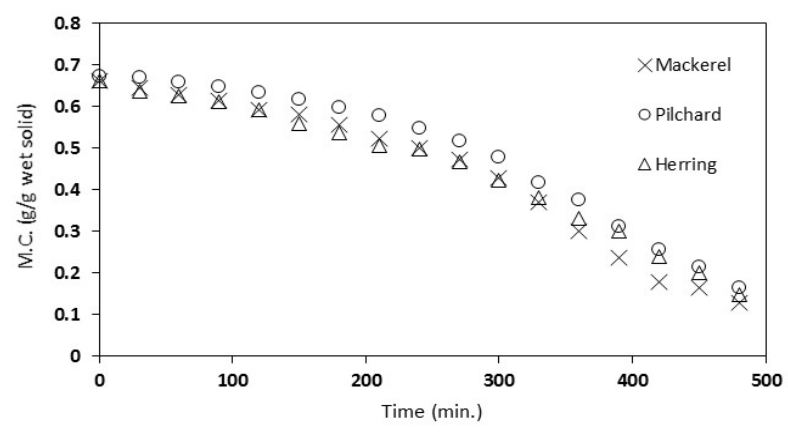

Figure 3. Moisture content as a function time at $60^{\circ} \mathrm{C}$ drying temperature

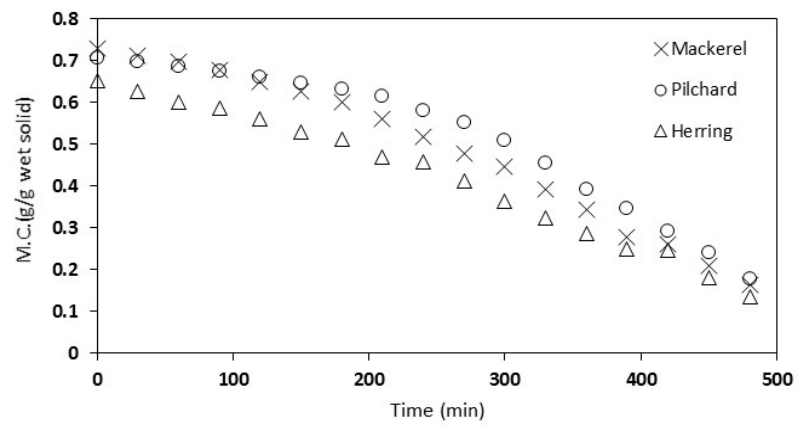

Figure 4. Moisture content versus drying time at $90 / 60^{\circ} \mathrm{C}$ drying te temperature

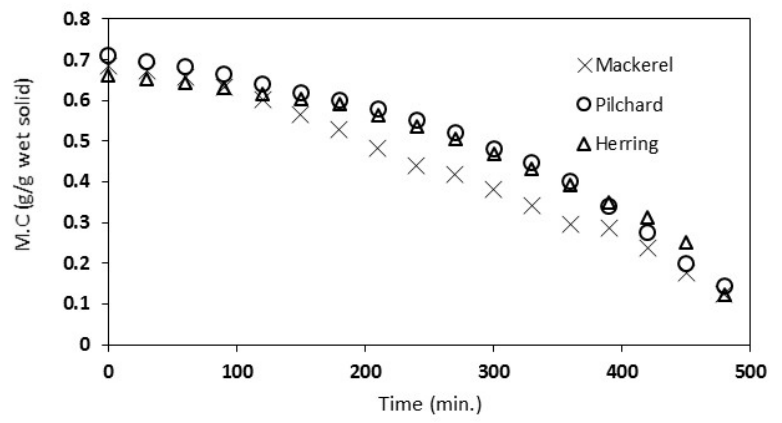

Figure 5. Moisture content versus drying time at $90^{\circ} \mathrm{C}$ drying temperature

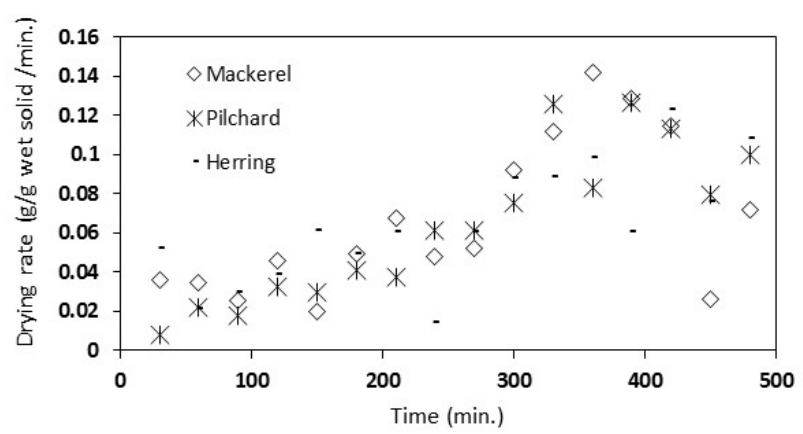

Figure 6. Drying rate as a function time at $60 \mathrm{oC}$ drying temperature 


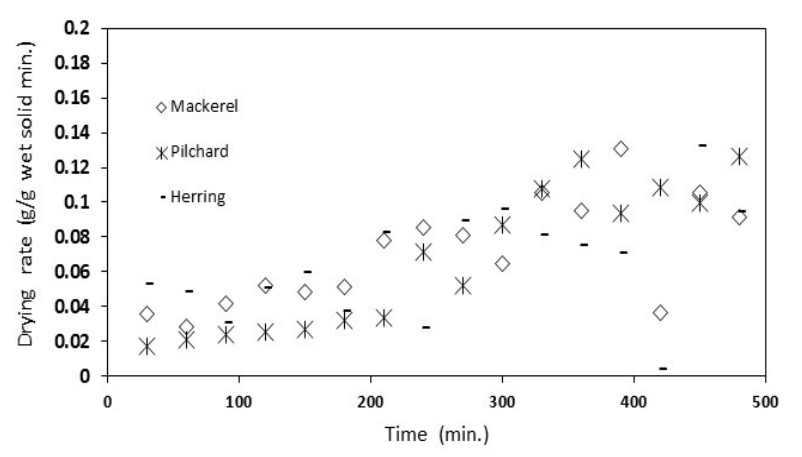

Figure 7. Drying rate as a function time at 90/60oC drying temperature

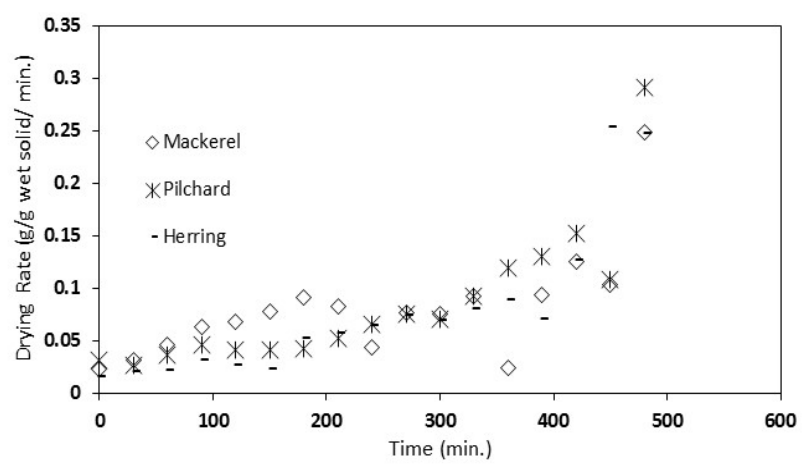

Figure 8. Drying rate as a function time at $90^{\circ} \mathrm{C}$ drying temperature

Figures 6-8 depict the relationship between the drying rate and time. The highest drying rate curves were observed in Figurer 8 (i.e. at $90^{\circ} \mathrm{C}$ drying temperature) as compared to two other Figurers (Figure 6 and 7). The highest drying rates obtained at $90^{\circ} \mathrm{C}$ drying temperature were $0.291,0.253$ and $0.246 \mathrm{~g} / \mathrm{g}$ wet solid min. for pilchard, herring and mackerel respectively. The interpretation of the results is that the higher the drying temperature, the faster the drying rate.

\subsection{Moisture diffusivity and activation energy}

Figures 9-11 present the variation of logarithm of moisture ratio with drying time at $60,90 / 60$ and $90{ }^{\circ} \mathrm{C}$ drying air temperature. From the Figures, the logarithm of moisture ratio decreased with the increase in drying time. The coefficient of determination $\left(\mathrm{R}^{2}\right)$ at $60,90 / 60$ and $90{ }^{\circ} \mathrm{C}$ drying air temperature for the three tilapia fish species (mackerel, pilchard and herring) were 0.982, 0.971 and 0.994; 0.997, 0.969 and 0.996; and 0.903, 0.811 and 0.746 respectively. The calculated effective diffusivities for the fish species are shown in Table 1. It is clearly evident from Table 1 that the increase in drying temperature resulted to increase in moisture diffusivity. The calculated moisture diffusivity value ranged between $7.821 \times 10^{-11}$ and $4.591 \mathrm{x}$ $10^{-10} \mathrm{~m}^{2} / \mathrm{s}$. The values of $D_{\text {eff }}$ obtained from this study are within the general range $10^{-12}$ to $10^{-8}$ for drying of food materials [34]. The predicted Arrhenius constant and activation energy were $2.221 \times 10^{-10} \mathrm{~m}^{2} / \mathrm{s}$ and $23.79 \mathrm{~kJ} / \mathrm{mol}$ respectively. The moisture diffusivity and activation energy values were in reasonable agreement with 0.11 and $0.25 \mathrm{x}$ $10^{-9} \mathrm{~m}^{2} / \mathrm{s}$ and $20.32 \mathrm{~kJ} / \mathrm{mol}$ for fish; $1.7 \times 10^{-10}$ and $1.15 \mathrm{x}$ $10^{-9} \mathrm{~m}^{2} / \mathrm{s}$ and 29.35 to $33.78 \mathrm{~kJ} / \mathrm{mol}$ for apricot fruit; $7.14 \mathrm{x}$ $10^{-9}$ and $3.70 \times 10^{-8} \mathrm{~m}^{2} / \mathrm{s}$ and 11.797 to $33.318 \mathrm{~kJ} / \mathrm{mol}$ for asparagus root reported by [35], [36] and [37]. Also, the predicted activation energy falls within the range 12.7 to $110 \mathrm{~kJ} / \mathrm{mol}$ reported by [38] for various foods. The sum of square error SSE and root mean square error RMSE of the calculated and predicted moisture diffusivity were $3.8756 \mathrm{x}$ $10^{-39}$ and $1.1142 \times 10^{-10} \mathrm{~m}^{2} / \mathrm{s}$.

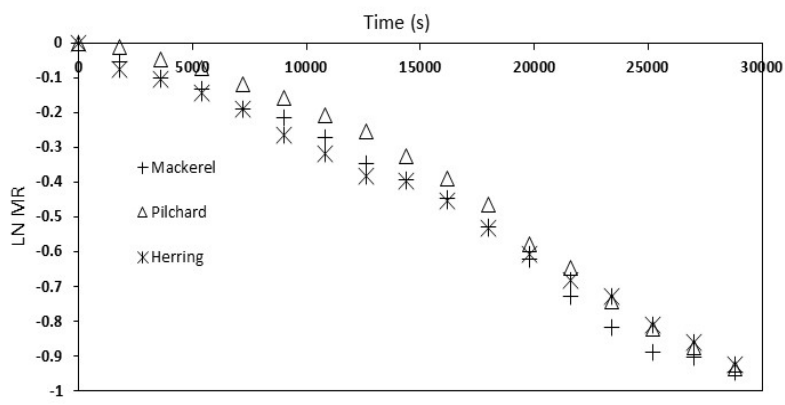

Figure 9. Variation of $\ln \mathrm{MR}$ with time at $60^{\circ} \mathrm{C}$ drying temperature

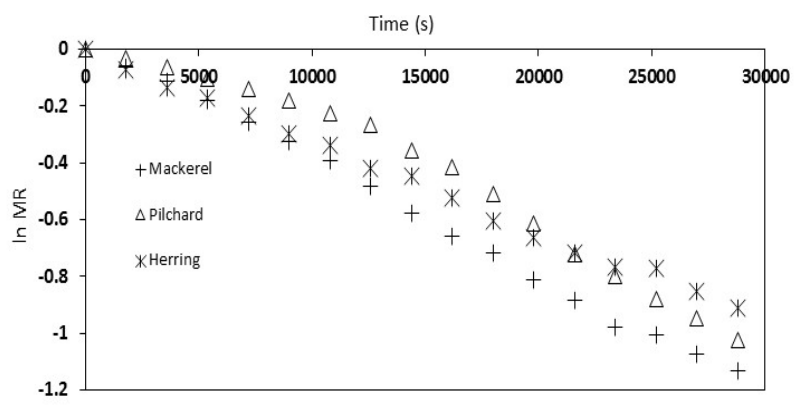

Figure 10. Variation of $\ln \mathrm{MR}$ with time at $90 / 60^{\circ} \mathrm{C}$ drying temperature

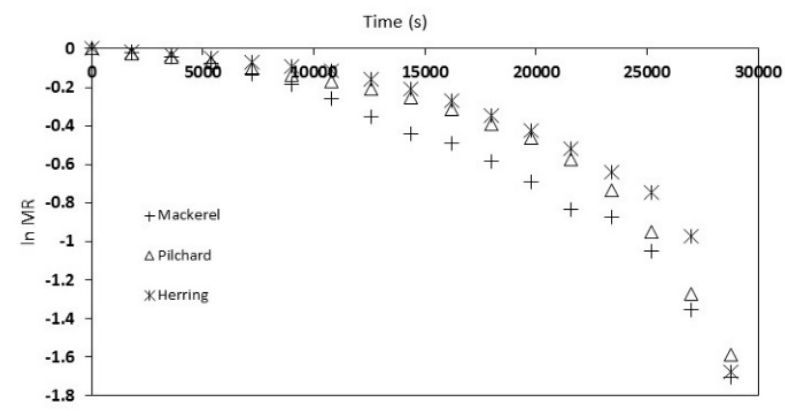

Figure 11. Variation of $\ln \mathrm{MR}$ with time at $90^{\circ} \mathrm{C}$ drying temp

Table 1. Calculated moisture diffusivity $\operatorname{De}_{\mathrm{ff}}\left(\mathrm{m}^{2} / \mathrm{s}\right)$

\begin{tabular}{ccc}
\hline $\begin{array}{c}\text { Fish } \\
\text { species }\end{array}$ & $\begin{array}{c}\text { Drying temp. } \\
\mathbf{0} \mathbf{C}\end{array}$ & $\begin{array}{c}\text { Moisture diffusivity } \\
\mathbf{m}^{\mathbf{2} / \mathbf{s}}\end{array}$ \\
\hline Mackerel & 60 & $1.133 \mathrm{E}-10$ \\
Pilchard & 60 & $1.159 \mathrm{E}-10$ \\
Herring & 60 & $7.821 \mathrm{E}-11$ \\
Mackerel & $(90 / 60)$ & $2.561 \mathrm{E}-10$ \\
Pilchard & $(90 / 60)$ & $1.961 \mathrm{E}-10$ \\
Herring & $(90 / 60)$ & $2.397 \mathrm{E}-10$ \\
Mackerel & 90 & $4.591 \mathrm{E}-10$ \\
Pilchard & 90 & $3.183 \mathrm{E}-10$ \\
Herring & 90 & $2.397 \mathrm{E}-10$ \\
\hline
\end{tabular}

Also, the moisture diffusivity values obtained lie within 
the range 5.997 and $3.358 \times 10^{-10} \mathrm{~m}^{2} / \mathrm{s}, 5.997$ and $3.358 \times 10^{-}$ ${ }^{10} \mathrm{~m}^{2} / \mathrm{s}, 5.18$ and $6.58 \times 10^{-10} ; 11.11$ and $8.708 \times 10-{ }^{11} \mathrm{~m}^{2} / \mathrm{s}$; $4.13 \times 10^{-10}$ and $1.83 \times 10^{-9} \mathrm{~m}^{2} / \mathrm{s}$ and $3.43 \times 10^{-10}$ and $29.19 \times$ $10^{-10} \mathrm{~m}^{2} / \mathrm{s}$ reported by [10], [11], [6], [39], [15] and [40] during solar dying of salted catfish; Microwave heating of sardine fish, microwave-vacuum drying of pomegranate arils, open sun drying of fish, cabinet drying of grapes leave and microwave drying of pomegranate arils respectively.

\section{CONCLUSION}

Moisture diffusivity and activation energy of three locally available tilapia fish species in Nigeria market were investigated and determined under three different drying temperatures. The following results were drawn from the experiments.

- The highest drying rates were observed during the convective drying process at $90{ }^{\circ} \mathrm{C}$ drying temperature.

- The calculated moisture diffusivity value ranged between $7.821 \times 10^{-11}$ and $4.591 \times 10^{-10} \mathrm{~m}^{2} / \mathrm{s}$.

- The predicted Arrhenius constant and activation energy were $2.221 \times 10^{-10} \mathrm{~m}^{2} / \mathrm{s}$ and $23.79 \mathrm{~kJ} / \mathrm{mol}$ respectively.

\section{REFERENCES}

[1] Komolafe CA, Ogunleye IO, Adejumo AOD. (2011). Design and fabrication of a convective fish dryer. The Pacific Journal of Science and Technology 12(1): 8997.

[2] Clucas IJ. (1982). Fish handling, preservation and processing in the tropics, Part 2. Report of Tropical Product Institute, G145, vii +144 . Tropical Institute, London, UK. pp. 3-9.

[3] Komolafe CA, Ogunleye IO, Adejumo AOD, Oladapo, MO. (2013). Effects of drying temperatures on the quality of three tilapia fish species. International Journal of Scientific Research and Management 1(12): 371-375.

[4] Aghbashlo M, Kianmehr MH, Samimi-Akhljahani H. (2008). Influence of drying conditions on the effective moisture diffusivity, energy of activation and energy consumption during the thin-layer drying of barberries fruit (Berberidaceae). Energy Conversion and Management 49: 2865-2871. https://doi.org/10.1016/j.enconman.2008.03.009

[5] Marinou-Kouris D, Maroulis ZB. (2006). Transport properties in the drying of solids. In A.S. Mujumdar ed. Handbook of industrial drying. Taylor and Francis Group LLC. London, UK.

[6] Dak M, Pareek NK. (2014). Effective moisture diffusivity of pomegranate arils undergoing microwave-vacuum drying. Journal of Food Engineering 122: 117-121. https://doi.org/10.1016/j.jfoodeng.2013.08.040

[7] Zogzas NP, Maroulis ZB, Marinous-Kouris D. (1994). Moisture diffusivity and activation methods of experimental determination: A review. Drying Technology 12(3): 483-515.

[8] Toujani M, Hassini L, Azzouz S, and Belghith A. (2012). Experimental study and Mathematical modelling of silverside fish convective drying. Journal of Food Processing and Preservation. ISSN: 17454549.

4549.2012.00729.x

[9] Chavan BR, Yakupitiyage A, Kumar S. (2008). Mathematical modelling of drying characteristics of Indian mackerel (Rastrilliger kangurta) in solarbiomass hybrid cabinet dryer. Drying Technology 26: 1552-1562. https://doi.org/10.1080/07373930802466872

[10] Mujaffar S, Sankat CK. (2015). Modelling the sun and solar cabinet drying behaviour of salted catfish (Arius sp.) slabs. First Nordic Baltic Drying Conference NBDC, Gdansk, Poland.

[11] Darvishi H, Azadbakht, M, Rezaeiasl A, Farhang, A. (2013). Drying characteristics of sardine fish dried with microwave heating. Journal of Saudi Society of Agricultural Science 12: 121-127. https://doi.org/10.1016/j.jssas.2012.09.002

[12] Akpinar EK, Toraman S. (2013). Estimation of the moisture diffusivity and activation energy in thin layer drying of ginger slices. International Journal of Nutrition and Food Engineering 7(6): 415-418.

[13] Taheri-Garavand A, Rafiee S, Keyhani A. (2011). Mathematical modelling of thin layer kinetics of tomato influence of air dryer conditions. International Transaction Journal of Engineering, Management, and Applied Science and Technologies 2(2): 148-160.

[14] Fiorentini C, Demarchi SM, Quintero Ruiz NA, Torrez Irigoyen RM, Giner SA. (2015). Arrhenius activation energy for water diffusion during drying of tomato leathers. The concept of characteristic product temperature. Biosystems Engineering 132: 39-46. https://doi.org/10.1016/j.biosystemseng.2015.02.004

[15] Doymaz I. (2011). Air drying characteristics, effective moisture diffusivity and activation energy of grapes leaves. Journal of Food Processing and Preservation. ISSN $1745-4449 . \quad$ https://doi.org/10.1111/j.17454549.2011.00557.x

[16] Meziane S, Mesbahi N. (2012). Determination of moisture diffusivity and activation energy in thin layer drying of olive pomace. International Journal of Food Engineering 8(3). https://doi.org/10.1515/15563758.2648

[17] Khanali M, Banisharif MA, Rafiee S. (2016). Modelling of moisture diffusivity, activation energy and energy consumption in fluidized bed drying of rough rice. Heat Mass Transfer. https://doi.org/10.1007/s00231-016-1763-z

[18] So'bah A, Mohd SA, Farah ST, Rosnah S, Siti Roha, AM. (2017). Effective moisture diffisivity and activation energy of rambutan seed under different drying methods to promote storage stability. Mechanical Engineering, Science and Technology. IOP Conf. Series. Material Science and Engineering 203: 012025 .

[19] Hii CL, Ogugo JF. (2014). Effect of pre-treatment on the drying kinetics and product quality of star fruit slices. Journal of Engineering Science and Technology 9(1): 123-135.

[20] Ndukwu MC, Dirioha C, Abam FI, Ihediwa VE. (2017). Heat and mass transfer parameters in drying of cocoyam slices. Case Studies in Thermal Engineering 9: 62-71. https://doi.org/10.1016/j.csite.2016.12.003

[21] Balocco C, Petrone G. (2018). Heat and moisture 
transfer investigation of surface building materials. Mathematical Modelling of Engineering Problems 5(3): 146-152.

[22] Binici A, Kaya GK. (2017). Effect of brine and dry salting methods on the physicochemical and microbial quality of chub (Squalius cephalus Linnaeus, 1758. Food Science and Technology. https://doi.org/10.1590/1678-457x.15717

[23] Komolafe CA, Ogunleye IO, Adejumo AOD. (2011). The performance evaluation of a convective fish dryer. International Journal of Advances in Science and Technology 2(5): 58-64.

[24] Rahman MS. (2006). Drying of fish and seafood. In A.S. Mujumdar ed. Handbook of industrial drying. Taylor and Francis Group LLC. London, UK.

[25] Serafica E, Del MR. (2003). Design and qualitative performance of a hybrid solar-biomass powered dryer for fish. Proceedings of the World Renewable Energy Congress ix, National Engineering Centre, Diliman, Quezon City, Philippines 1101.

[26] AOAC (2000). Official methods of analysis. $17^{\text {th }}$ ed. Association of Official Analytical Chemist. Washington, DC, USA.

[27] Dinani ST, Hamdami N, Shahedi M, Havet M. (2014). Mathematical modelling hot air/electrohydrodynamic (EHD) drying kinetics of mushroom slices, Energy conversion and Management 86: 70-80. https://doi.org/10.1016/j.enconman.2014.05.010

[28] El-Sebaii AA, Shalaby SM. (2012). Solar drying of agricultural products: A review. Renewable and Sustainable Energy Review 16: 27-43. https://doi.org/10.1016/j.rser.2011.07.134

[29] Doymaz I. (2005) Sun drying of Figures. An experimental study. Journal of Food Engineering 71: 403-407. https://doi.org/10.1016/j.jfoodeng.2004.11.003

[30] Fernando JAKM, Amarasinghe ADUS. (2016). Drying kinetics and mathematical modeling of hot air drying of coconut coir pith. Research 5: 807. https://doi.org/10.1186/s40064-016-2387-y

[31] Dina FS, Ambarita H, Napitupulu FH, Kawai H. (2015). Study of continuous solar dryer integrated with desiccant thermal storage for drying cocoa beans. Case Studies in Thermal Engineering 5: 32-40. https://doi.org/10.1016/j.csite.2014.11.003

[32] Crank J. (1975). The mathematics of diffusion. $2^{\text {nd }}$ ed. Oxford University press, Oxford, UK.

[33] Clement AD, Emmanuel AN, Patrice K, Benjamin YK, (2009). Mathematical Modelling of Sun Drying Kinetics of Thin Layer Cocoa (Theobroma Cacao) Beans. Journal of Applied Sciences Research 5(9): 1110-1116.

[34] Zogzas NP, Maroulis ZB, Marinos-Kouris D. (1996). Moisture diffusivity data compilation in foodstuffs.
Drying Technology 14: 2225-2253. https://doi.org/10.1080/07373939608917205

[35] Dongbang H, Pirompugd W. (2015). Experimental study on drying kinetics of anchovy using centrifugal fluidized bed techniques. Int J Agric and Biol Eng 8(5): 132-141. https://doi.org/10.3965/j.ijabe.20150805.1975

[36] Mirzaee E, Rafiee S, Keyhani A, Emam-Djomeh Z. 2009. Determination of moisture diffusivity and activation energy in the drying of apricots. RES. AGR. ENG 55(3): 114-120. https://doi.org/10.17221/8/2009RAE

[37] Kohli D, Shahi NC, Kumar A. (2017). Drying kinetics and activation energy of Asparagus root (Asparagus racemosus wild) for different methods of drying. Current Research in Nutrition and Food Science 6(1): 191-202. https://doi.org/10.12944/CRNFSJ.6.1.22

[38] Troncoso E, Pedresch F. (2007). Modelling of textural changes during drying of potato slices. Journal of Food Engineering 82: 577-584. https://doi.org/10.1016/j.jfoodeng.2007.03.015

[39] Jain D, Pathare PB. (2007). Study the drying kinetics of open sun drying of fish. Journal of Food Engineering 78: 1315-1319. https://doi.org/10.1016/j.jfoodeng.2005.12.044

[40] Minaei S, Motevali A, Najafi G, Seyedi S. (2011). Influence of drying methods on activation energy, effective moisture diffusion and drying rate of pomegranate arils (Punica Granatum). Australian Journal of Crop Science AJCS 6(4): 584-591.

\section{NOMENCLATURE}

$\begin{array}{ll}\text { Deff } & \text { moisture diffusivity }\left(\mathrm{m}^{2} / \mathrm{s}\right) \\ \text { D } & \text { Arrhenius constant }\left(\mathrm{m}^{2} / \mathrm{s}\right) \\ \text { DR } & \text { drying rate }\left(\mathrm{g} \mathrm{H}_{2} \mathrm{O} / \mathrm{g} \text { wet solid } \mathrm{h}\right) \\ \text { E } & \text { activation energy }(\mathrm{kJ} / \mathrm{mol}) \\ \text { L } & \text { half thickness of } \mathrm{slab}(\mathrm{mm}) \\ \text { M } & \text { moisture content }(\%) \\ \text { MR } & \text { moisture ratio }(\text { dimensionless }) \\ \text { R } & \text { Universal gas constant }(8.314 \mathrm{~J} / \mathrm{mol} . \mathrm{K}) \\ \text { T } & \text { temperature }(\mathrm{K}) \\ \text { W } & \text { weight of sample }(\mathrm{g})\end{array}$

\section{Subscripts}

$\begin{array}{ll}\mathrm{dt} & \text { change in time }(\mathrm{hr}) \\ \mathrm{e} & \text { equilibrium } \\ \mathrm{f} & \text { final } \\ \mathrm{i} & \text { initial } \\ \mathrm{m} & \text { moisture } \\ \mathrm{t} & \text { drying time }(\mathrm{hr})\end{array}$

